\title{
Parental Knowledge, Attitude, and Behavior towards Basic Immunization
}

\author{
Vicky Sagita Hanka, ${ }^{1}$ Edward Surjono ${ }^{2}$ \\ ${ }^{1}$ School of Medicine and Health Sciences Atma Jaya Catholic University, Jakarta, Indonesia, ${ }^{2}$ Department of \\ Pediatrics, School of Medicine and Health Sciences Atma Jaya Catholic University, Jakarta, Indonesia
}

\begin{abstract}
Immunization, which is usually done by giving vaccinations, is the process of forming immunity in individuals against infectious diseases. The target in the Strategic Plan of the Ministry of Healht of the Republic of Indonesia in 2015-2019 aimed for $93 \%$ of coverage. However, according to the report of the Indonesian Basic Health Survey (IBHR), there is actually a decrease in basic immunization coverage for the period of 2012-2015 when compared to the previous period. This study aimed to determine the correlation between parental knowledge, attitudes, and behavior towards complete course of basic immunization among parents of an elementary school in North Jakarta, Indonesia, in 2018 and 2019. This was a cross-sectional analytical descriptive study involving 110 respondents. Data were obtained through a questionnaire that was distributed to parents that included questions on knowledge, attitude, and behavior towards complete basic immunization. Out of 110 respondents, $70 \%$ stated that their child received the full basic immunization course while the remaining $30 \%$ stated that their child only received some of the vaccines required in the basic immunization course. There was no correlation, based on the bivariate analytical test, between parental behavior $(\mathrm{p}=0.868)$, parental attitude $(\mathrm{p}=0.647)$, and full course of basic immunization. In contrast, parental knowledge influences whether the child will receive the full course of basic immunization or not $(\mathrm{p}=0.000)$.
\end{abstract}

Keywords: Attitude, behavior, complete basic immunization, knowledge

\section{Pengetahuan, Sikap, dan Perilaku Orangtua Terhadap Imunisasi Dasar}

\begin{abstract}
Abstrak
Imunisasi merupakan proses terbentuknya imun pada individu terhadap penyakit infeksi, yang biasa dilakukan dengan pemberian vaksinasi. Target Renstra (Rencana Strategis Kementrian Kesehatan) tahun 2015-2019 diharapkan dapat mencapai 93\%. Namun menurut data RISKESDAS terjadi penurunan cakupan imunisasi periode 2012-2015 dibanding dengan periode sebelumnya. Penelitian ini dilakukan untuk mengetahui hubungan pengetahuan, sikap, dan perilaku orangtua terhadap imunisasi dasar lengkap di SDN Kapuk Muara 03 Jakarta Utara tahun 2018 dan 2019. Penelitian ini merupakan penelitian deskriptif analitik dengan pendekatan potong lintang, melibatkan 110 responden yang terdiri atas orangtua pada SDN Kapuk Muara 03. Pengambilan data dilakukan pada bulan November 2018 hingga September 2019. Data didapatkan dengan meminta orangtua mengisi kuesioner pengetahuan, sikap dan perilaku mengenai imunisasi dasar lengkap. Hasil penelitian didapatkan dari 110 responden $70 \%$ diantaranya menjawab memiliki status imunisasi dasar lengkap dan 30\% responden menjawab tidak lengkap. Hasil uji analisis bivariat ditemukan tidak terdapat hubungan antara sikap orangtua $(p=0,868)$ dan perilaku orangtua $(p=0,647)$ terhadap kelengkapan imunisasi dasar. Namun, pengetahuan orang tua $(p=0.000)$ memiliki hubungan yang bermakna terhadap kelengkapan imunisasi dasar. Kelengkapan imunisasi dasar seorang anak dipengaruhi oleh tingkat pengetahuan yang dimiliki oleh orangtuanya.
\end{abstract}

Kata kunci: Imunisasi dasar lengkap, pengetahuan, perilaku, sikap

Corresponding Author: Vicky Sagita Hanka School of Medicine and Health Sciences Atma Jaya Catholic University, Jalan Pluit Selatan Raya No. 19, Jakarta Utara 14440, Indonesia, Email: vicky.2016060058@student.atmajaya.ac.id 


\section{Introduction}

Immunization, which is usually performed by giving vaccinations, aims at developing immunity in individuals against infectious diseases. ${ }^{1}$ In 2013, the World Health organization (WHO) estimates 1 in 5 children, or 21.8 million children, did not receive immunization to save their lives. In 2016, 19.4 million babies did not get basic immunization, such as DPT (diphtheria-tetanuspertussis) vaccination where $60 \%$ of these children came from developing countries, such as Indonesia.

In Indonesia, immunization coverage has reached $86.8 \%$ and still needs to be improved to be able to achieve the goal stated in the Strategic Plan of the Ministry of Health of the Republic Indonesia 2015-2019 for basic immunization coverage, which is 93\%. Data from the 2016 Indonesian Basic Health Research (IBHR) in 2016 demonstrated a gradual decrease in immunization coverage in the period of 20122015 when compared to the coverage in 20082011. Decreased basic immunization coverage may link to several factors such as families refuse to vaccinate their children, lack of awareness of the benefits of immunization, and difficulty in accessing immunization service in remote areas. Several factors influence Indonesia's immunization activities including, among others, the level of parent's knowledge, attitude, and behavior. $^{1}$

This research aimed to determine the correlation between parent's knowledge, attitude, and behavior and basic immunization in an elementary school, SDN 03 Kapuk Muara, in North Jakarta.

\section{Methods}

This was a cross-sectional analytical descriptive study conducted from November 2018 to September 2019 in an elementary school in North Jakarta, Indonesia (SDN 03 Kapuk Muara. This study involved 110 respondents who were sampled using simple random sampling method from parents of elementary school students. The sample size was determined using the Lemeshow formula, resulting in a minimum of 96 respondents, and additional 15\% of the minimum sample size was added to anticipate sample shortages, leading to a sample size of 110 respondents.

Data were obtained by asking parents to complete a questionnaire regarding knowledge, attitude, and behavior towards their child's basic immunization status. The dependent variable of this study was completion of basic immunization program while the independent variables included respondent's demographic data (age, educational stage, and income) and parents' knowledge, attitude, and behavior towards basic immunization. Basic immunization program in Indonesia consists of Hepatitis B, BCG, polio, DPT-HB-HIB, and measles vaccines.

The scoring for knowledge items were performed based on the correct answers. If a respondent scored below 55\%, he or she would be categorized as having lack of knowledge. A score of 56-75\% was considered to represent adequate knowledge while a score of $76-100 \%$ was categorized as having good level of knowledge. Attitude and behavior were scored based on the median score from all the respondents.

Respondents were divided into three age groups of 17-25 years (late adolescence), 2635 years (early adult), 36-45 years (late adult), and 46-55 years (elderly) while education was categorized into elementary school graduate, junior high school graduate, senior high school graduate, college graduate (diploma 3), and university graduate (bachelor). Income was categorized into three groups of average-to-high, average, and average-to-low income. ${ }^{2}$

Data were analyzed using the chi-square test in SPSS program and were tested using the Fisher exact test with a 95\% confidence interval if one of the cross-tabulation values was below five. ${ }^{3}$ Significance was declared if $\mathrm{p}$-value below 0.05 . This study has already been approved by the research ethics commission of the faculty of medicine and health science, Atma Jaya Catholic University, Jakarta, Indonesia under the issuance of the ethical clearance number 06/11/KEPFKUAJ/2018.

\section{Results}

Female comprised the majority of the (98.2\%), with most respondents were in their early adulthood (47.3\%), graduated from senior high school (36.4\%), and had average to low income (77\%) (Table 1). Seventy seven of 110 respondents stated that their children had completed the basic immunization program (Table 2).

Most respondents had adequate knowledge, positive behavior, and good attitude towards basic immunization status. It was demonstrated 
Table 1 Respondents Demographic Characteristics

\begin{tabular}{lcc}
\hline \multirow{2}{*}{ Characteristics } & \multicolumn{2}{c}{ Total } \\
\cline { 2 - 3 } Gender & $\mathbf{n}$ & $\mathbf{( \% )}$ \\
$\quad$ Women & 108 & 98.2 \\
Men & 2 & 1.8 \\
Age & & \\
$\quad$ Late teen & 0 & 0 \\
$\quad$ Early adult & 52 & 47.3 \\
$\quad$ Late adult & 50 & 45.5 \\
$\quad$ Early eldery & 8 & 7.3 \\
Educational Background & & \\
$\quad$ Category 1 Elementary School & 39 & 35.5 \\
$\quad$ Category 2 Junior High School & 30 & 27.3 \\
$\quad$ Category 3 Senior High School & 40 & 36.4 \\
$\quad$ Category 4 Bachelor/Diploma & 1 & 0.9 \\
3 & & \\
Income & & \\
$\quad$ Average to high income & 6 & 5.5 \\
$\quad$ Average income & 27 & 24.5 \\
$\quad$ Average to low income & 77 & 70.0 \\
\hline
\end{tabular}

Table 2 Basic Immunization Status

\begin{tabular}{lcc}
\hline \multirow{2}{*}{ Status } & \multicolumn{2}{c}{ Total } \\
\cline { 2 - 3 } & $\mathbf{n}$ & $\mathbf{\%}$ \\
\hline Complete & 77 & 70.0 \\
Incomplete & 33 & 30.0 \\
\hline
\end{tabular}

that 19 of 20 respondents with good knowledge had completed the basic immunization program for their children. Among respondents with adequate knowledge, 47 of 64 respondents had also completed the basic immunization program for their children (Table 4).

Based on the correlation test using the chisquare test, a correlation was identified between knowledge $(\mathrm{P}=0.000)$ and complete basic immunization status. However, no correlation was seen between demographic characteristics, parental behavior $(\mathrm{p}=0.868)$, parental attitude $(\mathrm{p}=0.647)$ and completed basic immunization program (Table 3 and Table 4).

\section{Discussion}

This study addresses the concern regarding the percentage of children completing basic immunization program that is still lower than the national target. As already mentioned, the national target for 2015-2019 is 93\%. This study demonstrated that $70 \%$ of parents participating in this study have completed basic immunization program for their children. This low coverage of immunization may be due to several factors including knowledge, attitude, and behavior. Other factors that also influence whether a child will be fully vaccinated or not are parental educational background, age, and income.

No correlation is evident between parental age, level of education, income, and completed

Table 3 Demographic Characteristics

\begin{tabular}{|c|c|c|c|c|c|c|c|}
\hline & \multicolumn{4}{|c|}{ Basic Immunization Status } & \multirow{2}{*}{\multicolumn{2}{|c|}{ Total }} & \multirow{3}{*}{$\begin{array}{c}\text { p-value } \\
\text { (fisher's } \\
\text { Exact } \\
\text { Test) }\end{array}$} \\
\hline & \multicolumn{2}{|c|}{ Complete } & \multicolumn{2}{|c|}{ Incomplete } & & & \\
\hline & $\mathbf{n}$ & $\%$ & $\mathbf{n}$ & $\%$ & $\mathbf{n}$ & $\%$ & \\
\hline \multicolumn{8}{|l|}{ Parental Age } \\
\hline Early Adult & 36 & 69.2 & 16 & 30.8 & 52 & 100 & \\
\hline Late adult & 36 & 72.0 & 14 & 28.0 & 50 & 100 & .809 \\
\hline Early Elderly & 5 & 62.5 & 3 & 37.5 & 8 & 100 & \\
\hline \multicolumn{8}{|l|}{ Level of Knowledge } \\
\hline Elementary School & 27 & 69.2 & 12 & 30.8 & 39 & 100 & \\
\hline Junior High School & 19 & 63.3 & 11 & 36.7 & 30 & 100 & 681 \\
\hline Senior High School & 30 & 75.0 & 10 & 25.0 & 40 & 100 & \\
\hline Undergraduate/Diploma (S1/D3) & 1 & 100.0 & 0 & $0.0 \%$ & 1 & 100 & \\
\hline \multicolumn{8}{|l|}{ Parental Income } \\
\hline Average-to-low income $(<\mathrm{Rp} 2,600,000)$ & 56 & 72.7 & 21 & 27.3 & 77 & 100 & \\
\hline $\begin{array}{l}\text { Average income }(\mathrm{Rp} 2,600,000 \\
-6,000,000)\end{array}$ & 19 & 70.4 & 8 & 29.6 & 27 & 100 & .162 \\
\hline Average-to-high income $(>\mathrm{Rp} 6,000,000)$ & 2 & 33.3 & 4 & 66.7 & 6 & 100 & \\
\hline
\end{tabular}


Table 4 Corellation between Parental Knowledge, Attitude, Behavior, and Child's Complete Basic Immunization Status

\begin{tabular}{|c|c|c|c|c|c|c|c|}
\hline & \multicolumn{4}{|c|}{ Basic Immunization Status } & \multirow{2}{*}{\multicolumn{2}{|c|}{ Total }} & \multirow{3}{*}{$\begin{array}{c}\text { p-value } \\
\text { (Chi-square } \\
\text { Test) }\end{array}$} \\
\hline & \multicolumn{2}{|c|}{ Complete } & \multicolumn{2}{|c|}{ Incomplete } & & & \\
\hline & $\mathbf{n}$ & $\%$ & $\mathbf{n}$ & $\%$ & n & $\%$ & \\
\hline \multicolumn{8}{|l|}{ Knowledge } \\
\hline Good Knowledge & 19 & 95.0 & 1 & 5.0 & 20 & 100 & .000 \\
\hline Enough Knowledge & 47 & 73.4 & 17 & 26.6 & 64 & 100 & \\
\hline Lack of Knowledge & 11 & 42.3 & 15 & 57.7 & 26 & 100 & \\
\hline \multicolumn{8}{|l|}{ Attitude } \\
\hline Positive & 41 & 70.7 & 17 & 29.3 & 58 & 100 & .868 \\
\hline Negative & 36 & 69.2 & 16 & 30.8 & 52 & 100 & \\
\hline \multicolumn{8}{|l|}{ Behavior } \\
\hline Good & 41 & 71.9 & 16 & 28.1 & 57 & 100 & .647 \\
\hline Bad & 36 & 67.9 & 17 & 32.1 & 53 & 100 & \\
\hline
\end{tabular}

basic immunization program in this study. However, age has been known to play a significant role in learning new things and knowledge. ${ }^{4}$ Based on the findings of Prihanti et al., children of mothers aged below 25 years have better immunization status than those from mothers aged above $25 .^{4}$ the higher immunization status in this study shows that maternal age influences the experience of child care and preventive measures to protect the child from diseases. However, this is not a sole factor as immunization status is also influenced by other factors. ${ }^{1}$

Education is a continuous process of learning in a formal institution. A study by Triana et al. in Padang city discovered no correlation between maternal education and child's complete basic immunization status. ${ }^{5}$ This is probably due to the fact that in their study, 95\% of mothers have a high level of education. ${ }^{5}$ In contrast, Rahmawati et al. found that the percentage of mothers whose child has completed basic immunization status is higher among mothers who attend nine years of education when compared to those who attend below nine years of education. ${ }^{1}$ Thus, it seems that higher education leads to the ease of absorbing information. ${ }^{1}$ It is assumed in this study that there are other factors than maternal education that also influence the status of basic immunization in children.

People with good income have easier access to medical care; however, no correlation was found by Tahaib et al., as also supported in this study, between income and complete basic immunization status. ${ }^{6}$ In Tahaib et al., $84 \%$ of respondents have average-to-high income, still no correlation was seen. ${ }^{6}$ The present study demonstrated that this is due to the fact that parents know that they can get basic immunization for free as depicted in the questionnaire that 103 out of 110 respondents answered that basic immunization is a government program that is provided without any charge.

Knowledge is formed and embedded from the experiences of a person and some other factors such as belief, perspective, and principle. ${ }^{7}$ Knowledge has been shown to be correlated with complete basic immunization status as all, but one, respondents with good knowledge have their children complete their immunization regimen. ( $p$-value $=0.05)$. Theoretically, knowledge plays a role in explaining why parents with good knowledge tend to complete basic immunization. ${ }^{5}$ This finding supports Triana et al.'s finding that there is a correlation between knowledge and complete basic immunization status (p-value $=0.007) .^{5}$

Attitude, based on the theory of Alport, consists of three components: belief, idea, and concept about things, social life, and propensity to act. ${ }^{8}$ No correlation between attitude and basic immunization status found in this study. The same result is presented Albertina et al. where no significant difference between those with positive and negative attitude, which might be due to imbalance number of total respondents in each group. ${ }^{9}$ Contrary to this finding, Hudhah et al. concluded that there is a correlation between mother's attitude and child's basic immunization status. ${ }^{10}$ This significant correlation stems from the fact that belief, experience, and support from their public figure encourage these mothers 
to get basic immunization regimen for their children..$^{10}$ The lack of correlation in the present study might link to the study population, which is SDN 03 Kapuk Muara, North Jakarta, that does not require certificate of basic immunization program completion as one of the requirements for admission since 2019.

No correlation is evident in this study between behavior and complete basic immunization status despite the fact that behavior is one of the essential factors in preventive measures. Behavior is the result of attitude and belief that can be modified to make better interventions. ${ }^{11}$ Since behavior can be influenced by attitude, if people around a person have positive attitude and positive belief on immunization, and vice versa. A positive behavior related to basic immunization may be seen when there is positive attitude and belief among people living in an area as these aspects will not only influence the person but also individuals in surrounding areas. ${ }^{11}$ This may explain why there are individuals with poor behavior related to basic immunization but still have their children fully vaccinated according to the basic immunization program.

This study has limitation as researchers did not interview the respondents directly because it was challenging to do so when data collection was conducted in an open area.

In conclusion, there is no correlation between parental attitude, parental behavior, and complete basic immunization status. However, parental knowledge indeed influences complete basic immunization status in children.

\section{References}

1. Rahmawati AI, Umbul C. Faktor yang mempengaruhi kelengkapan imunisasi dasar di kelurahan krembangan utara. J Berk Epidemiol. 2014;2:59-70.

2. Penghasilan Kelas Menengah Naik $=$ Potensi Pajak-Badan Pendidikan dan Pelatihan Keuangan. Available from: http://www.bppk. kemenkeu.go.id/id/publikasi/artikel/167- artikel-pajak/21014-penghasilan-kelasmenengah-naik-potensi-pajak

3. Kim HY. Statistical notes for clinical researchers: Chi-squared test and Fisher's exact test. Restor Dent Endod. 2017;42(2):152-5.

4. Prihanti GS, Rahayu MP, Abdullah MN. Faktor-faktor yang memepengaruhi status kelengkapan imunisasi dasar di wilayah kerja Puskesmas X Kota Kediri. Saintika Medika: Jurnal Ilmu Kesehatan dan Kedokteran Keluarga. 2016;12(2):120-8.

5. Triana V. Faktor Yang berhubungan dengan pemberian imunisasi dasar lengkap pada bayi tahun 2015. J Kesehat Masy Andalas. 2017;10(2):123-35.

6. Thaib T, Darussalam D, Yusuf S, Andid R. Cakupan imunisasi dasar anak usia 1-5 tahun dan beberapa faktor yang berhubungan di Poliklinik Anak Rumah Sakit Ibu dan Anak (RSIA) Banda Aceh. Sari Pediatr. 2016;14(5):283-7.

7. Budiman AR. Pengetahuan dan sikap dalam penelitian kesehatan. Jakarta: Salemba Medika; 2013.

8. Trushitkumar P, Pathak R, Singh R, Alves V, Mahesh NM, Chaluvaraj TS, et al. Assessment of parents' knowledge, attitude and practice about child vaccination in Rural areas. J Pharm Res. 2017;16(3):229.

9. Albertina M, Febriana S. Kelengkapan imunisasi dasar anak balita dan faktorfaktor yang berhubungan di poliklinik anak beberapa rumah sakit di Jakarta dan sekitarnya pada bulan Maret 2008. Sari Pediatr. 2016;11(1):1-7.

10. Hudhah MH, Hidajah AC. Perilaku ibu dalam imunisasi dasar lengkap di Puskesmas Gayam Kabupaten Sumenep. J PROMKES. 2018;5(2):167-80.

11. Gore P, Madhavan S, Curry D, McClung G, Castiglia M, Rosenbluth SA, et al. Predictors of childhood immunization completion in a rural population. Soc Sci Med. 1999;48(8):1011-27. 